\title{
A PHENOMENOLOGICAL STUDY ON ORGANIZATIONAL CONFLICT MANAGEMENT
}

\author{
DOI: 10.17261/Pressacademia.2020.1321 \\ RJBM-V.7-ISS.4-2020(4)-p.239-252
}

\section{Ahmet Ilhan}

Bayburt University, Faculty of Health Sciences, Department of Health Management, Bayburt, Turkey. ahmetilhandr@gmail.com, ORCID: 0000-0003-2857-800X

\begin{tabular}{l}
\hline Date Received: October 22, $2020 \quad$ Date Accepted: December 14, 2020 \\
\hline To cite this document \\
Ilhan, A. (2020). A phenomenological study on organizational conflict management. Research Journal of Business and Management (RJBM), \\
V.7(4), p239-252. \\
Permanent link to this document: http://doi.org/10.17261/Pressacademia.2020.1321 \\
Copyright: Published by PressAcademia and limited licensed re-use rights only.
\end{tabular}

\section{ABSTRACT}

Pupose- The aim of this study is developing and evaluating various approaches to effectively diagnose, analyse, manage and control the conflict in organizations within the context of Pondy's organizational conflict model.

Methodology- This study used phenomenological design, a qualitative research method. The sample of the research consists of the employees of a private sector enterprise operating in Gaziantep. The sample consists of 17 employees. The research was carried out between November and December 2019 with the participation of the employees. Accordingly, in line with the purpose of the research, in the research question form there are open-ended questions prepared together with demographic questions in order to determine the perception of organizational conflict.

Findings- The results of the analysis show that Pondy's organizational conflict types that occur most throughout the enterprise are perceived and felt types of conflict. This situation gives us unilateral (perceived) or mutual (felt) anxiety, hostility, polarization, disappointment between individuals or groups depending on the nature of the work, jealousy, performance and target differences and priority positioning in the context of perceived and felt conflicts throughout the enterprise. It shows that emotional reactions are experienced and developed.

Conclusion- As a result of the research, it was determined that with the help of Pondy's organizational conflict model, managers can have the chance to detect, control and manage the conflicts that occur within the business. At the same time, the findings, if a solution to the conflicts can be found until the stage of open conflict with the detection of the conflict; It shows that the managers can help them with future-oriented cooperation, organizational performance and business development at the organizational level and enable them to develop different solution-oriented strategies.

Keywords: Organizational conflict, Pondy's organizational conflict model, organizational conflict management, phenomenological research JEL Codes: M10, M12, M19

\section{ÖRGÜTSEL ÇATIŞMA YÖNETIMININ INCELENMESINE YÖNELIK FENOMENOLOJIK BIRR ARAŞTIRMA}

\section{ÖZET}

Amaç- Bu çalışmanın amacı Pondy'nin örgütsel çatışma modeli bağlamında örgütlerde; çatışmayı etkin bir şekilde teşhis etmek, analiz etmek, yönetmek ve kontrol etmek için çeşitli yaklaşımlar geliştirerek değerlendirmelerde bulunmaktır.

Yöntem- Bu çalışmada, nitel araştırma yöntemlerinden birisi olan fenomenolojik (olgu bilim) araştırma deseni kullanılmıştır. Araştırma örneklemini Gaziantep ilinde özel sektörde faaliyet gösteren bir işletmenin işgörenleri oluşturmaktadır. Örneklemde 17 işgören bulunmaktadır. Araştırma, Kasım ve Aralık 2019 tarihleri arasında işletmede çalışan işgörenlerin katılımı ile gerçekleştirilmiştir. Buna göre araştırmanın amacı doğrultusunda araştırma soru formunda; örgütsel çatışma olgusuna yönelik olarak oluşan algıyı tespit edebilmek için demografik sorularla birlikte hazırlanan açık uçlu sorular yer almaktadır.

Bulgular- Analiz sonuçları ele alınan işletme genelinde en çok meydana gelen Pondy'nin örgütsel çatışma türlerinin algılanan ve hissedilen çatışma türleri olduğunu göstermektedir. Bu durum bize işletme genelinde, algılanan ve hissedilen çatışmalar bağlamında işin niteliği, kıskançlık, performans ile hedef farklılıkları ve öncelik konumlama nedenlerine bağlı olarak bireyler veya gruplar arasında tek taraflı (algılanan) ya da karşılıklı (hissedilen) düzeyde tedirginlik, düşmanlık, kutuplaşma, hayal kırıklığına uğrama biçiminde duygusal tepkilerin geliştirildiğini ve yaşandığını göstermektedir.

Sonuç- Araştırma sonucunda Pondy'nin örgütsel çatışma modeli yardımıyla yöneticilerin işletmede meydana gelen çatışmaları tespit etme, kontrol etme ve yönetme şansına sahip olabilecekleri belirlenmiştir. Aynı zamanda bulgular, çatışmaların tespit edilmesiyle birlikte açık çatışma aşamasına kadar çatışmalara çözüm yolu bulunabildiği takdirde yöneticilere; örgütsel düzeyde geleceğe yönelik iş birliği, örgütsel performans ve iş geliştirme konularında yardımcı olabilecek ve farklı çözüm odaklı stratejiler geliştirmelerine imkân sağlayabileceklerini göstermektedir.

Anahtar Kelimeler: Örgütsel çatışma, Pondy'nin örgütsel çatışma modeli, örgütsel çatışma yönetimi, fenomenolojik araştırma JEL Kodları: M10, M12, M19 


\section{GíRiş}

Çatışma, çok eski zamanlardan beri var olan ve düşünce sistemimizi etkileyen farklı bilim dalları tarafından araştırma konularına dâhil edilen bir olgu olarak karşımıza çıkmaktadır. İlerleyen dönemlerle birlikte çatışma bir fenomen haline gelip ekonomistler, sosyologlar, tarihçiler, biyologlar ve psikologlar tarafından farklı araştırmalar bağlamında araştırılıp varlığı sorgulanarak açıklanmaya çalışılmıştır. Örgüt araştırmalarında çatışma bir fenomen olarak yirminci yüzyılın sonlarına doğru yapılan bilimsel araştırmalarla gündeme gelmeye başlamıştır. Böylece sosyal ve örgütsel bağlamda çatışma ile ilgili yapılan çalışmalarda yenilenen ve ilgi gören önemli değişiklikler ortaya konulmuştur (Rahim, 2011: 1). Özellikle bireyler grup halinde çalıştıkları zaman çatışmanın ortaya çıkması olası bir sonuçtur. Bu bakımdan birçok yönetici, örgüt içinde zamanlarının büyük bir kısmını insanlarla ilgili sorunlardan kaynaklanan çatışmaları tespit etmek ve çözümlemek için harcamaktadırlar. Dolayısıyla çatışmaların doğru yönetilmesi; işgücüne doğru enerji dağılımının sağlanması, iletişim hatalarının önüne geçilmesi ve fırsatların değerlendirilmesi gibi örgütsel kazanımların elde edilmesine yol açmaktadır (Madalina, 2016: 808).

Son dönemlerde örgütsel çatışma konusunda geniş ve büyüyen bir literatür vardır. Çatışma kavramı, örgütler içindeki ve arasındaki çatışmanın anlaşılmasına yönelik çıkarımlarla birlikte genel bir sosyal fenomen olarak ele alınmıştır (Pondy, 1967: 296). Özellikle bireyler, gruplar, örgütler ve uluslar gibi iki veya daha fazla sosyal varlık hedeflerine ulaşma noktasında birbirleriyle temas kurduğu zaman insan etkileşiminin doğal bir sonucu olarak insanlar arasında çatışmanın ortaya çıkması kaçınılmazdır. Bu tür varlıklar arasında; iki veya daha fazla kişinin yetersiz tedarik edilen benzer bir kaynağı istediğinde uyumsuz veya tutarsız hale gelmesi, ortak eylemleriyle ilgili kısmen dışlayıcı davranış tercihlerine sahip olmaları veya farklı tutumları, değerleri, inançları ve becerilerinin olduğu ilişkiler sonucunda çatışmanın ortaya çıkması söz konusudur (Rahim, 2011: 1). Genellikle çatışmaların bireylerin zihinlerinde olumsuz ve yıkıcı olarak algılanan bir yansıması vardır. Buna karşılık iyi yönetilen çatışmanın olumlu sonuçlarını gösteren önemli kanıtlar ileri sürülmektedir. Bu kapsamda çatışmanın; farklı teorik bakış açılarını kullanan araştırmacılar tarafından değeri, örgütsel ve sosyal yaşamın diğer merkezi yönlerine katkıları olduğu ifade edilmiştir. Buradan çatışmanın kendisinin yıkıcı olmadığını ve yapıcı bir şekilde yönetildiğinde sorunları incelememize, anlamamıza, çözümler üretmemize ve ilişkileri güçlendirmemize yardımcı olabileceği çıkarımını yapabiliriz. Dolayısıyla çatışmayı anlama, çözme ve yönetme konusunda uygulamaya yönelik eylemlerin gerçekleştirilmesi büyük önem taşımaktadır (Tjosvold, 2006: 87-88).

Örgütler faaliyetlerinde çalışma takımlarını kullanmaya devam ettikleri sürece çalışma takımlarının iş yapma biçimlerinin doğal bir özelliği olmasından dolayı çatışmalardan kaçınılması zordur. Çatışma, davranışların bir sonucu olup insan hayatının ayrılmaz bir parçasıdır. Doğal olarak etkileşim olduğu zaman çatışma vardır. Dolayısıyla çatışma; düşmanlığın, olumsuz tutumların, saldırganlığın, rekabetin ve yanlış anlaşılmanın sonucunda meydana gelebilir. Aynı zamanda iki karşıt grup arasında çelişkili tutum ve davranışları içeren durumlarla da ilişkili bir süreç olarak değerlendirilebilir (Thakore, 2013: 7). Bununla birlikte çatışma, bazıları için farklı görüşlere sahip insanlara sunulan sürekli bir yaşam armağanı iken bazıları için ise çatışma, her ne pahasına olursa olsun kaçınılması gereken olumsuz bir durum olarak görülmektedir. Diğer bir ifadeyle çatışma örgütsel düzeyde yönetim gerektiren bir değişken olarak görülebilir. Aynı zamanda bazen insanlar çatışmayı kişisel gelişimim için heyecan verici bir fırsat olarak görebilir ve bu yüzden onu en iyi şekilde kullanmaya çalışabilir. Çatışmayla ilgili bu farklı bakış açılarının, istihdam temeli olarak örgütsel düzeyde farklı koşulsal durumlar bağlamında kullanılması beklenebilir. Dolayısıyla çatışma süreci, yöneticinin rolü için önemli olup temel düzeyde esas olarak işletme, sosyoloji, psikoloji gibi alanlardan kaynaklanmaktadır (Omisore ve Abiodun, 2014: 119). Bu bağlamda örgütsel düzeyde çatışmayı etkin bir şekilde teşhis etmek ve yönetmek için farklı yöntemler geliştirmek oldukça önemlidir. Söz konusu önem, çatışmanın karmaşık yapısından ve bilişsel, psikolojik, fizyolojik ve bağlamsal dinamiklerin etkileşiminden kaynaklanmaktadır. Bu bakımdan çatışmayı anlamak ve yönetmek bağlamında bireyler ve gruplar arasındaki bir çatışmayı azaltmak veya çözmek için uygun psikolojik ve ekonomik temellerde örgütsel çatışma modeli yaklaşımı benimsenmelidir (Madalina, 2016: 808)

Bu çalışmanın amacı örgütsel çatışma modeline göre örgütlerde; çatışmayı etkin bir şekilde teşhis etmek, analiz etmek, yönetmek ve kontrol etmek için çeşitli yaklaşımlar geliştirmeyi sağlamaktır. Bu araştırmada örgütsel düzeyde işletmelerde yaşanan çatışma düzeyini ve örgüt içinde Pondy'nin örgütsel çatışma modeline göre hangi çatışma aşamalarının meydana geldiğinin tespit edilmesi amaçlanmaktadır. Bu amacın gerçekleştirilmesiyle birlikte yöneticiler, örgütsel çatışma modeli kapsamında örgüt içinde meydana gelen çatışmaların ortaya çıkış nedenlerine bakmaksızın çatışmayı analiz edip çözüme yönelik alternatif stratejiler geliştirebilirler. Buna göre çalışmanın ilk kısmında örgütsel çatışma kavramı ele alınıp incelenmeye çalışılmıştır. Daha sonra ikinci kısımda örgütsel çatışma yönetimi yaklaşımı kavramsal düzlemde incelenip yapısı, gelişimi ve özellikleri bir bütün halinde değerlendirmeye tabi tutulmuştur. Üçüncü bölümde ise bir örgütte çatışmayı tespit etmek, kontrol altına almak ve yönetmek için Louis R. Pondy tarafından geliştirilen ve kullanılan bir araç olan Pondy'nin Örgütsel Çatışma Modeli incelenmiştir. Son olarak sonuç ve öneriler kısmıyla örgütlerde meydana gelen çatışmanın belirlenmesi ve kullanılan model yardımıyla örgütsel düzeyde çatışmanın yönetilmesine yönelik öngörüler ve çıkarımlarda bulunmaya çalışılmıştır.

\section{2. ÖRGÜTSEL ÇATIŞMA KAVRAMI}

Çatışma, farklı anlamlara sahip olan çok yönlü bir kavramdır. Buna göre, çatışmayı kişilerarası düşmanlık olarak düşünmek oldukça meşru görünmektedir. Bununla birlikte çatışmayı iki kişi arasında bir seçim veya tercih konusunda yaşanan anlaşmazlık veya anlaşmazlık algısı olarak düşünmek de aynı derecede meşrudur. Çatışma, söz konusu bu tür anlaşmazlıkları çözememe olarak veya sadece resmi olarak tanımlanmış çeşitli işler arasındaki uyumsuzluklar olarak ifade edilebilir (Pondy, 1966: 246). Geleneksel olarak, çatışmanın kıt kaynaklar içeren karşıt çıkarlardan, hedef farklılaşmasından ve hayal kırıklığından 
kaynaklandığı düşünülmektedir. Çatışmanın, kişilerin hem rekabetçi hem de işbirliği çıkarlarına sahip olduğu karma içerikli ilişkilerde ortaya çıktığı ileri sürülmektedir. Bununla birlikte rekabetçi unsurlar çatışmayı üretir ve işbirliği yönündeki unsurlar ise belirli bir anlaşmaya varmak için pazarlık yapmaya teşvik eder. Rubin vd. (1994), çatışmanın çok geniş bir yapıya sahip olduğunu belirtmiş ve çatışmayı; "algılanan bir çıkar ayrılığı veya tarafların mevcut özlemlerinin aynı anda gerçekleştirilemeyeceğine dair bir inanç" anlamında ifade etmişlerdir. Rubin vd. (1994) ile Lewicki vd. (1997), çatışmayı tanımlamanın birçok yolu olduğunu ileri sürmüş ve çatışmayı; "uyumsuz hedefler algılayan ve bu hedeflere ulaşmada birbirlerinin müdahalesini algılayan birbirine bağlı insanların etkileşimi" biçiminde ifade etmişlerdir (Tjosvold, 2006: 88-89).

\section{Şekil 1: Çatışma Döngüsü}

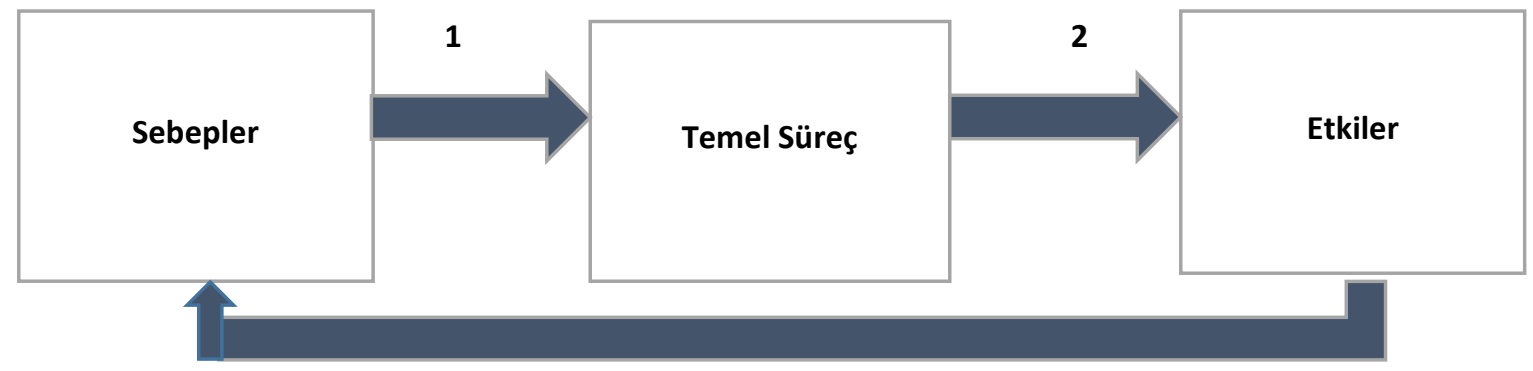

3

\section{Geri Bildirim}

Kaynak: Wall ve Callister, 1995: 516

Çatışma kavramsal olarak uzun zamandır üzerinde tartışılan ve araştıılan bir olgu olarak değerlendirilmektedir. Özellikle örgütler, bireyler veya gruplar arasında çatışma, güçlü baskılar karşısında kişinin değerlerine veya inançlarına ters düştüğünde veya bireyin herhangi bir roldeki farklı talepleri aynı anda karşılanamadığında ortaya çıkması mümkündür. Aynı zamanda bireysel düzeyde çatışma roller arası çatışma biçimine de dönüşebilir. Bu durumda, bireyin birden fazla rolü işgal etmesi ve her rolden bazı taleplerin aynı anda karşılanamayacağını görmesi nedeniyle de çatışma ortaya çıkabilir. Söz konusu bu düzeylerde yaşanabilecek her türlü çatışmalar Şekil 1'de genel bir düzeyde sunulmaktadır. Buna göre herhangi bir sosyal süreçte olduğu gibi çatışmada da sebepler olup ayrıca söz konusu sebeplerin sonuçları ve etkilerinin olduğu temel bir süreç bulunmaktadır. Döngüsel olarak bu etkiler, nedenleri etkilemek için geri bildirimde bulunur. Böyle bir çatışma döngüsü bir bağlam içinde gerçekleşir ve döngü çok sayıda yinelemeden geçmektedir (Wall ve Callister, 1995: 515-516). Diğer yandan çatışma dinamik bir süreç olarak kabul edilirse anlaşılması daha kolay olabilir. Bir örgütte iki veya daha fazla kişi arasında meydana gelen çatışma ilişkisi örgütsel düzeyde bir dizi çatışma dönemi olarak analiz edilebilir. Ele alınan her çatışma bölümü, belirli çatışma potansiyelleri ile birlikte karakterize edilen koşullarla başlar. Söz konusu bu durumda ilişkinin tarafları, herhangi bir çatışma temelinin farkına varmayabilir ve birbirlerine karşı düşmanca bir tutum geliştiremezler. Dolayısıyla çeşitli faktörlere bağlı olarak davranışlar çeşitli düzeylerde çatışmalı özellikler gösterebilir. Her bölüm veya bireyler arasındaki etkileşim sonraki bölümlerin seyrini etkileyen bir sonuç bırakma özelliğini taşır. Daha sonra tüm ilişki koşulların, duyguların, algının ve davranışların belirli sabit yönleriyle karakterize edilip ortaya çıkan bu özelliklerin herhangi birindeki eğilimlerle desteklenebilir (Pondy, 1967: 299).

Roloff (1987)'a göre örgütsel çatışma, üyelerin kendi çevrelerindeki meslektaşları, diğer toplulukların üyeleri veya örgütün hizmetlerini ya da ürünlerini kullanan bağımsız bireylerle uyumsuz faaliyetlerde bulundukları durumlarda ortaya çıkan bir süreç olarak ifade edilmektedir. Diğer bir ifadeyle çatışmayı sosyal varlıklar olan bireyler, gruplar ve örgütler arasında uyumsuzluk veya anlaşmazlık şeklinde ortaya çıkan bir süreç olarak değerlendirebiliriz. Bu bakımdan çatışmayı etkileşimli bir süreç olarak adlandırmak yerinde olacaktır (Rahim, 2002: 207). Bununla birlikte örgütsel çatışma, herhangi bir kişinin hedeflerine ulaşmasını engellemeyi amaçlayan davranışlar bütünü olarak ifade edilebilir. Dolayısıyla çatışma, hedeflerin uyumsuzluğunun bir ürünü olup karşıt davranışlardan kaynaklanmaktadır (Thakore, 2013: 8). Bütün bunların sonucunda örgütsel çatışma konusunda, bir birey veya grubun kendisi ile başka bir birey veya grup arasındaki çıkarlar, inançlar veya konularla ilgili farklılıkları ve zıtlıkları algılamasıyla meydana gelen bir süreç olarak görüldüğü noktasında bir çıkarımda bulunmak mümkündür. Buna bağlı olarak örgütsel çatışma, iş ve görevle ilgili sorunlar veya sosyo-duygusal ve ilişki sorunları etrafında algılanan farklılıklar ve muhalefet, iş ve görevle ilgili sorunlara bă̆lı olarak gelişim gösterir. Bu yüzden örgütsel çatışmalar; kaynakların dağııımı ve tahsisi ile ilgili anlaşmazlıkları, yapılması veya uyulması gereken prosedürler ve politikalarla ilgili muhalif görüşleri veya örgütsel düzeyde gerçeklerin farklı koşulsal yargılarını ve yorumlarını içermektedir (De Dreu ve Beersma, 2005: 106).

\section{3. ÖRGÜTSEL ÇATIŞMA YÖNETIMI}

Örgütsel çatışma yönetimi, genel olarak örgütlerde üzerinde durulması gereken önemli bir görev olarak kabul edilmiştir. Birçok örgüt için işbirliğine ve takım halinde çalışmaya vurgu yapılmış ve insanların farklılıkların üstesinden gelebilmeleri gerektiği ifade edilmiştir. Örgütsel çatışma yönetiminin altında yatan fikirler özellikle karmaşık değildir, ancak çoğu örgütte hâkim olan kültürel normlardan farklı bir özellik göstermektedir. Dolayısıyla bir örgütün çatışmayı yönetmeye ilişkin yeni bir 
yaklaşım geliştirmesi için bazı önemli değişiklikler gerekli olması beklenmelidir (Conbere, 2001: 215). Bu bakımdan çatışma yönetimi, mümkün olduğu sürece çatışmayı önlemek için gerekli olan planlamayı yapmayı ve hızlı ve etkili önlemler almayı gerektirmektedir (Madalina, 2016: 809).

Anderson (1990) ve Burton (1987), çatışma yönetiminin geniş bir uygulama alanına sahip olduğunu ileri sürmüşlerdir. Burton (1987), örgütsel çatışma yönetiminin önemli özelliğinin, statükonun uyuşmazlığı yönetme veya çatışmanın tırmanmasını önleme girişimi olduğunu ifade etmiştir. Bu bakımdan örgütsel düzeyde çatışma çözümü, çatışmanın nedenini ele almayı veya ortadan kaldırmayı ifade eder (Thakore, 2013: 11-12). Wall ve Callister (1995)'in örgütsel çatışmayı ele alırken örgütsel çatışmanın hem işlevsel hem de işlevsel olmayan sonuçları olduğunu ileri süren yaklaşımları olmuştur. Bununla birlikte Eisenhardt, Kahwajy ve Bourgeois (1998), örgütsel düzeyde üst yönetimde çatışmanın kaçınılmaz olduğunu ve bu durumun genellikle değerli olduğunu ifade etmişlerdir. Özellikle; esaslı, bilişsel veya konuya yönelik çatışma olarak adlandırılabilecek uygun eylem yollarını çevreleyen üst düzeylerde çatışmaların etkili stratejik seçimler için çok önemli olduğunu vurgulamışlardır. Bu nedenle, Wall ve Callister (1995)'in örgütsel çatışmanın azaltılmasını veya sona erdirilmesini içeren çatışma çözümü alanına yönelik bir eğilim gösterdikleri sonucuna ulaşabiliriz (Rahim, 2002:208). Diğer yandan örgütsel çatışma yönetimi, bir örgütün işyerindeki anlaşmazlıklara ve zor düzeyde sorunlara yanıt vermek için kullandığı genel bir yaklaşımdır. Örgütsel çatışma yönetim sisteminin tasarlanması ve uygulanması, genel olarak çalışanların çatışmayı çözmelerine yardımcı olacak yapılar oluşturmayı ve bu yapıları kullanmasına olanak tanıyan iletişim ve eğitimi içeren organize bir değişim sürecinin başlangıcı kabul edilmektedir (Conbere, 2001: 215-216). Bu noktada örgütlerin, çatışmaya karşı açık olmaları ve ortaya çıkan çatışmaların yöneticilere örgütsel sorunları tespit etmede ve çözüme yönelik alternatif uygulamalar için kararlar alma konularında kolaylık sağladığını bilmeleri gerekir (Jones, 2017: 410). Bununla birlikte çağdaş nitelikli örgütler için gerekli olan şey çatışma yönetimidir. Örgütsel çatışma yönetimi; sadece çatışmanın önlenmesi, azaltılması veya sona erdirilmesi anlamına gelmez. Aynı zamanda çatışmanın işlevsel bozukluklarını en aza indirmek için etkili makro düzeyde stratejiler tasarlamayı ve örgütsel öğrenmeyi ve etkinliği artırmak için çatışmanın yapıcı işlevlerini geliştirmeyi amaçlamaktadır (Rahim, 2002: 208).

Örgütsel çatışmayı yönetmenin yolları; nedenleri, kökenleri ve bağlamları kadar çeşitli düzeylere sahiptir. Buna göre çatışma yönetiminin amacı, ister çatışma halindeki taraflarca üstlenilsin isterse dışarıdan bir tarafın müdahalesini içeriyor olsun çatışma sürecindeki yıkıı bileşenleri içerecek şekilde bir çatışma durumunun tüm yapısını etkilemektir. Dolayısıyla etkili düzeyde bir örgütsel çatışma yönetimi, herhangi bir çatışmanın varlı̆ı̆ndan kaynaklanan kesintiyi en aza indirmede ve tatmin edici kabul edilebilir bir çözüm sağlamada başarılı olabilme olasılığı yüksektir (Thakore, 2013: 11-12). Diğer bir ifadeyle örgütsel çatışmalar doğru, etkin ve sağduyulu bir yönetim anlayışıyla yönetilip kontrol altına alınırsa örgütsel düzeyde performans ve verimlilik artırılıp süreç başarıyla yürütülmüş olur (Demir Uslu, 2018: 123). Tüm örgütler basit veya karmaşık bir yapıya sahip olsalar da çatışmayı yönetmek için çeşitli mekanizmalara veya prosedürlere sahiptir. Söz konusu bu tür mekanizma veya prosedür gibi araçların başarısı ya da etkinliği, çatışma davranışını ne ölçüde sınırladıkları ve tatmin edici bir çözüme ulaşmaya ne ölçüde yardımcı oldukları ile değerlendirilebilir (Thakore, 2013: 12).

Örgütlerde ortaya çıkan çatışma genellikle yöneticileri farklı stratejiler geliştirmeye ve uygulamaya yönlendirmektedir. Bunun sonucunda çatışmayı yönetmek için örgütsel düzeyde farklı nitelikte stratejiler uygulanmaktadır. Bu bağlamda örgütsel çatışmalar çözüme yönelik olarak çeşitli yollarla birlikte yönetilebilir. 1920'lerin başında, Follett (1942) çatışma çözme yaklaşımlarını; hâkimiyet, uzlaşma, bütünleşme, kaçınma ve bastırma olarak tanımlamıştır. Deutsch (1949) ise işbirliği ya da rekabeti içeren bir yapı önermiştir. Bununla birlikte çatışma stillerini sınıflandırmak için ilk kavramsal şema oluşturulmuştur. Blake ve Mouton (1964) tarafından çatışmayı ele almanın beş farklı yönetim tarzı tanımlanmış ve sunulmuştur: Bunlar; zorlama, geri çekme, yumuşatma, uzlaşma ve problem çözme şeklinde sıralanmaktadır (Montes, Rodriguez ve Serrano, 2012: 7). Bu model örgütsel çatışmayı yönetecek uzmana, bir kişinin önemli konulara ve çatışmaya dâhil olan diğer taraf veya taraflar ile olan ilişkisine ne kadar değer verdiğine ilişkin değerlendirmesine dayalı olarak kişinin müzakerede benimseyeceği tarzı tahmin etme imkânı vermektedir (Trippe ve Baumoel, 2015: 91). Bu yönetim tarzlarından her biri yöneticilerin; statüsüne, değerlerine ve dâhil olan varlıklara bağlı olarak uygun türden örgütsel çatışma yönetimi araçlarını nasıl ayırt edeceklerini bilmeleri ve kullanmaları bakımından önem taşımaktadır (Madalina, 2016: 810). Rahim ve Bonoma (1979), çatışma tarzlarını iki temel boyutta farklılaştırmış ve ele almıştır. Bunlar; kendi çıkarını (ilgi düzeyini) düşünme ve başkalarının çıkarını (ilgi düzeyini) düşünme boyutlarıdır. İlk boyut, bir kişinin kendi çıkarını tatmin etmeye çalıştığı dereceyi (yüksek veya düşük) açıklar. İkinci boyut, bir kişinin başkalarının çıkarını tatmin etmeye çalıştı̆̆ı dereceyi (yüksek veya düşük) açıklar. Bu boyutların, bireyin çatışma sırasındaki motivasyonel yönelimlerini tasvir ettiği belirtilmektedir. Şekil 2'de iki boyutun birleşimi ile kişilerarası çatışmayı ele alan beş farklı spesifik tarz gösterilmektedir (Rahim, 2002: 216-217). 
Şekil 2: Kişilerarası Çatışmayı Ele Alma Tarzlarının İki Boyutlu Modeli Kendisi İçin Çıkar (ilgi) Düzeyi

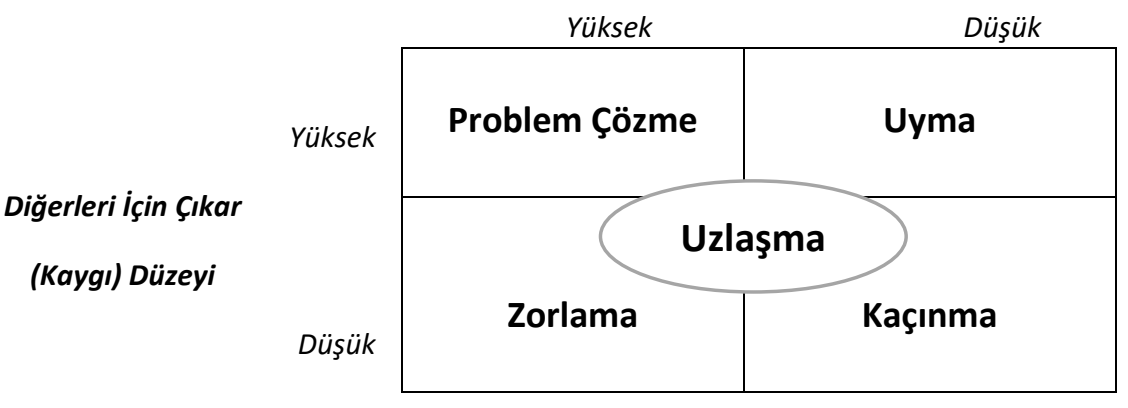

Kaynak: Rahim, 2002: 217

Şekil 2'de gösterilen örgütsel düzeyde çatışma yönetim tarzları modeline göre;

Problem Çözme: Örgütsel düzeyde kendisi ve diğerleri için yüksek çıkar (ilgi) boyutu düzeyine sahip bir çatışma yönetim tarzıdır. Problem çözme tarzı, doğru problemlerin teşhis edilmesinde ve tespit edilen bu sorunlara karşı yapılacak müdahale ile ilişkilidir. Bu tarzın kullanımı, her iki taraf için de kabul edilebilir düzeyde etkili bir çözüme ulaşmak için açıklık, bilgi alışverişi, alternatifler arama ve farklılıkların incelenmesini içermektedir. Aynı zamanda problem çözme çatışma tarzının karmaşık sorunlarla etkili bir şekilde başa çıkmak ve yönetmek için kullanışlı bir yapıya sahip olduğunu söylemek mümkündür (Rahim, 2002: 218).

Uyma: Örgütsel düzeyde kendisi için düşük diğerleri için yüksek çıkar (ilgi) boyutu düzeyine sahip bir çatışma tarzı olarak değerlendirilebilir. Buna göre uyma çatışma tarzı, farklılıkları azaltmaya çalışmak ve diğer tarafın çıkarını tatmin etmek için ortaklıkları vurgulamakla ilişkilidir. Yükümlü olan kişi, diğer tarafın çıkarını tatmin etme konusunda kendi çıkarını ihmal etmektedir (Rahim, 2002: 218-219).

Zorlama: Örgütsel düzeyde kendisi için yüksek diğerleri için düşük çıkar (ilgi) boyutu düzeyine sahip bir tarzdır. Genel olarak zorlama çatışma tarzı, kazan ya da kaybet yönelimi veya kişinin konumunu kazanmaya yönelik zorlama davranışı ile tanımlanmıştır. Zorlama tarzında, hâkim veya rakip olan bir kişi genellikle hedefini kazanmak için her şeyi yapar ve sonuç olarak diğer tarafın ihtiyaç ve beklentilerini göz ardı eder. Bu çatışma tarzı, herhangi bir çatışmaya dâhil olan taraf için konular önemli olduğunda veya diğer tarafın olumsuz bir kararı bu taraf için zararlı olabildiğinde kullanımı uygun olarak görülmektedir (Rahim, 2002: 220). Diğer bir ifadeyle bireyin karşı tarafın istek ve taleplerini göz ardı edip kendi taleplerini ve beklentilerini ön plana çıkarması zorlama çatışma tarzının genel görünümünü ifade etmektedir (Demir Uslu, 2018: 124).

Kaçınma: Örgütsel düzeyde hem kendisi hem de diğerleri için düşük çıkar (ilgi) boyutu düzeyine sahip bir yapı mevcuttur. Çatışmayla başa çıkma konusu kaçınma durumu ile ilişkilendirilmiştir. Birçok durumda insanlar, herhangi bir olay karşısında gergin bir duruma girme korkusuyla veya çatışmaları yönetme yeteneklerine yeterince güvenmedikleri için çatışmadan kaçınma eğilimi göstermektedirler. Söz konusu çatışma yönetimlerinden biri olan kaçınma yönteminin, gerilimleri azaltmak veya zaman kazanmak için küçük çatışma durumlarıyla uğraşırken ya da çatışmayı yönetme konumunda olan kişi hiyerarşi açısından daha aşağı bir konumda olduğunda uygulanması daha uygundur. Çatışmalardan kaçınmak; geri çekilme yeteneği, gerilimlerden kaçınma yeteneği ve zaman açısından planlama duygusu gerektirmektedir (Madalina, 2016: 810).

Uzlaşma: Örgütsel düzeyde kendisinin ve başkalarının çıkarlarını (ilgilerini) orta düzeyde ilgilendiren bir çatışma yönetim tarzıdır. Uzlaşma tarzı, her iki tarafın da karşıııkı olarak kabul edilebilir bir karar vermek için bir şeyden vazgeçtiği bir uzlaşmayı içerir. Bu tarz, çatışan tarafların hedefleri birbirini dışladığında veya her iki taraf eşit derecede güçlü olduğunda ve müzakere süreçlerinde bir çıkmaza varıldığında kullanılan yararıı bir çatışma yönetim tarzıdır (Rahim, 2002:220). Bireyler, sorunu çözme isteği yeterince yüksek olmadığında veya zaman sınırlamaları veya yüksek maliyetler içeren baskılar ortaya çıktığında sıklıkla uzlaşma tarzını kullanırlar. Uzlaşma, adalete hitap etme, takas önerisi, kazançları maksimize etme ve kayıpları en aza indirme ve hızlı, kısa vadeli bir çözüm sunma gibi taktikleri içermektedir (Montes, Rodriguez ve Serrano, 2012: 8).

Bireylerin çatışmalarını yönetme yöntemleri çok farklı düzeylerde olabilir. Araştırma ve kuramsal bağlamda, Blake ve Mouton'un (1964) çatışma yönetimi şemasında geliştirilen taksonomi üzerinde ortaya çıkan modelinde farklı tarzlar yer almaktadır. Buna göre bir bireyin hangi stratejiyi benimseyeceği, kendisiyle ilgili düşük veya yüksek çıkar (ilgi) düzeyinin yanı sıra başkalarına karşı olan yüksek veya düşük çıkar (ilgi) düzeyine bağlıdır. Dolayısıyla ortaya çıkan farklı düzeylerdeki boyutların etkileri farklı düzeylerde sonuçlar ortaya çıkarmaktadır. Böylece söz konusu boyutların operasyonel hale getirilmesinin özel yolları gündeme gelebilir. Bu noktada önemli olan bireylerin kendisinin ve diğerlerinin çıkarlarının (ilgilerinin) ve dolayısıyla çatışma yönetimi stratejilerinin hem kişiden hem de durumdan kaynaklanmasıdır. Bu nedenle, çatışma yönetimi sadece bir kişilik özelliği olarak görülmemeli, kompleks bir yapıya sahip olduğu göz önünde bulundurulmalıdır (De Dreu ve Beersma, 2005: 107-108). Diğer yandan her bireyin baskın bir çatışma tarzı olmasına rağmen, benimsenen tarz belirli bir duruma göre değişiklik gösterebilir. Bu bakımdan çatışma yaklaşımının herhangi bir çatışma tarzının 
tercih edilmesi bağlamında duygusal ipuçlarına oldukça duyarlı olduğu ileri sürülebilir (Montes, Rodriguez ve Serrano, 2012: 9). Bireylerin davranışlarının aynı etkileşim sırasında sıklıkla bir çatışma tarzından diğerine yönelik olarak değiştiğine dair kanıtlar ileri sürülmektedir. Bu nedenle çatışma tarzlarının çoğu için ilişkisel bakımdan hâkim olan rehber seçeneği belirlemenin değişkenlik gösteren bir durum olarak görüldüğü ifade edilebilir (Munduate, Ganaza, Peiro ve Euwema, 1999: 78).

\section{4. ÖRGÜTSEL ÇATIŞMA MODELI BILLEŞENLERi}

Örgütsel düzeyde yapılan faaliyetler sonucunda alınan kararların programlanması veya rutin hale gelmesi biçiminde bir örgüt içindeki çatışma yönetimi de bazen programlanır veya kurumsallaşma eğilimine girebilir. Aslında, tekrarlayan çatışmalarla başa çıkma araçlarının kurumsallaştırılması, konunun herhangi bir yönden ele alınmasında önemli yönlerden biri olarak görülebilir. Dolayısıyla bir örgütün başarısı, büyük ölçüde çeşitli çatışma fenomenleriyle başa çıkmak için geliştirilecek uygun mekanizmaları kurma ve çalıştırma becerisine bağlıdır (Pondy, 1967: 299-300). Diğer yandan örgütsel çatışma sistemi modeli örgütler içinde uyum ve işbirliğinin gerçekleşmesine yönelik olduğu ifade edilebilir. Elbette örgütsel düzeyde kimlerin tipik olarak uyum ve işbirliği çerçevesinde tartıştığını ve işbirliğinin şartlarını taşıdığını sorgulayabiliriz. Birçok örgütte, kendi örgütsel şartlarına göre işbirliğinin en güçlü destekçisi olarak iç grup görülmektedir. Bu nedenle örgütsel çatışma sistemi modelinde, örgütsel düzeyde meydana gelen çatışmalarda çatışmayı yönetmek ve kontrol altına almak için kullanılan bir model olarak değerlendirilebilir (Pondy, 1989: 97). Bununla birlikte örgütsel çatışma, aynı zamanda örgütsel öğrenmeyi de teşvik eden bir süreç olarak nitelendirilebilir. Dolayısıyla örgütsel düzeyde meydana gelen çatışmadan değer yaratacak şekilde yararlanmak ve fonksiyonel olmayan olumsuz etkilerinden kaçınmak için çatışmanın kontrol altına alınması ve yönetilmesi gerekir. Bu bağlamda Pondy (1967), örgütsel çatışmayı tespit etmek, yönetmek ve kontrol etmeye yönelik önerilerin yer aldığı bir model geliştirmiştir. Bu modelde örgütsel çatışmanın aşamaları örgütsel düzeyde incelemiş ve ele alınmıştır (Jones, 2017: 410). Buna göre örgütsel çatışma modelinde; bir çatışma olayının beş aşaması belirlenmektedir. Bunlar; (1) Örtük (gizli) çatışma, (2) Algılanan çatışma, (3) Hissedilen çatışma, (4) Açık çatışma ve (5) Çatışma sonrası biçiminde tanımlanan örgütsel çatışma modeli bileşenleridir (Pondy, 1967: 300; Jones, 2017: 410-411). Söz konusu bu aşamaların her birinin tespit edilip ayrıntılı olarak ele alınması meydana gelen bir çatışma olayının yönetiminde ve kontrol edilmesinde işleyen bir temel sağlayacaktır. Bir çatışma olayının her aşamasında hangi spesifik tepkiler meydana gelir ve neden, bir çatışma teorisinde cevaplanacak temel soruların neler olduğu belirlenir. Burada sadece bu soruların sistematik olarak araştırılabileceği ve incelenebileceği bir çerçeve geliştirilmiştir (Pondy, 1967: 300).

Şekil 3: Örgütsel Çatışma Modeli Bileşenleri

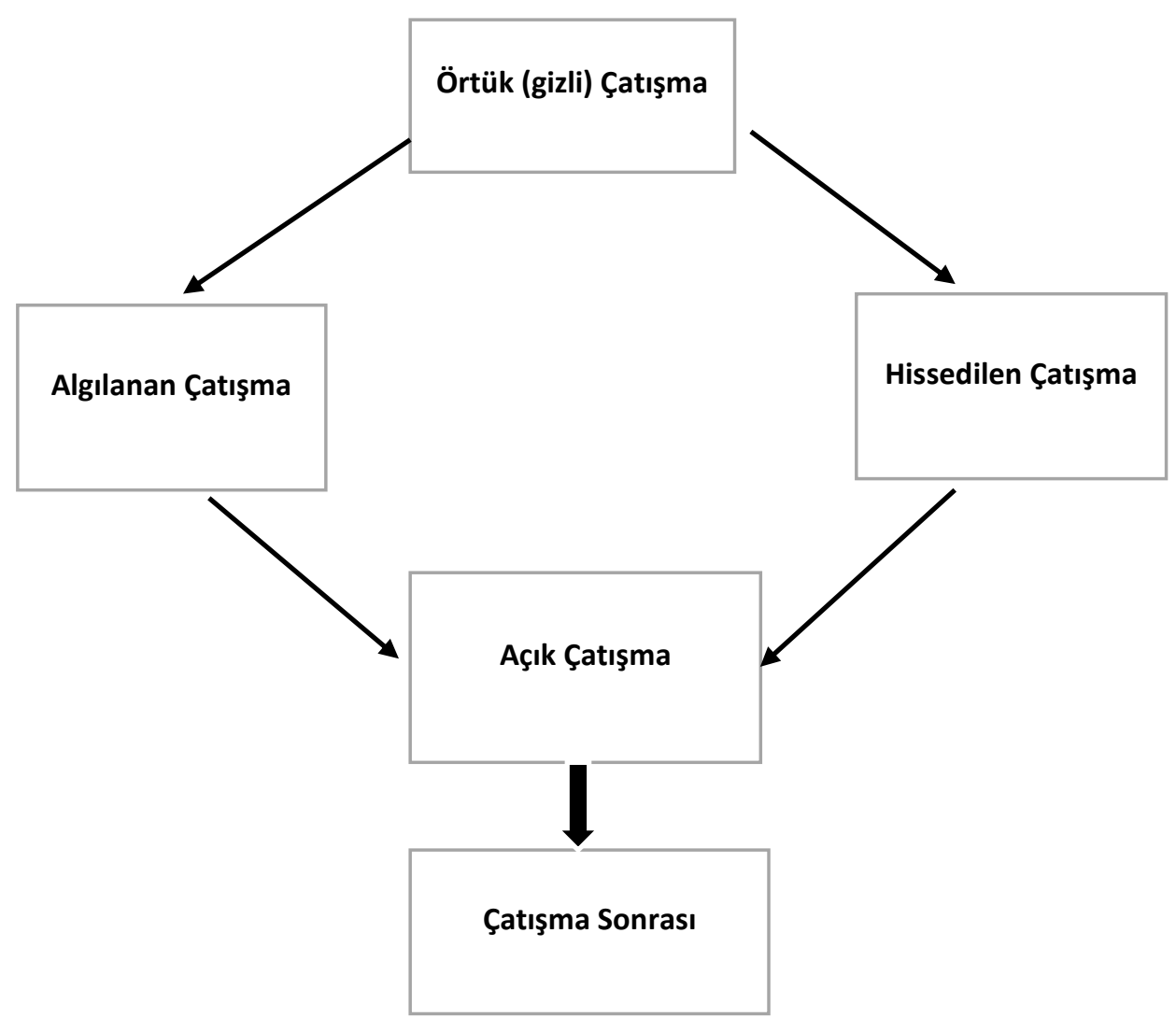

Kaynak: Pondy, 1967: 306 
Örgütler, kapalı bir sistem olmadığından dolayı içinde bulundukları ortam işbirliğine daha uygun bir hale getirilebilir ve böylece örgütlere daha fazla kaynak sağlayarak örneğin örtük çatışma koşulları hafifletilebilir. Buna karşılık daha kötü niyetli ve sorunlu bir ortam beraberinde yeni krizleri ortaya çıkarabilir. Dolaysıyla her bir çatışma bölümünün gelişimi, önceki bölümlerin ve çevre ortamının etkilerinin karmaşık bir bileşimi tarafından belirlenir. Bu bağlamda örgütsel çatışma modelinin bileşenleri şekil 3'te özetlenmiştir (Pondy, 1967: 306).

\section{1. Örtük Çatışma}

Örgütsel çatışma modelinin ilk aşaması olan örtük çatışma aşamasında, doğrudan bir çatışma yoktur. Buna karşılık ise örgütün iş yapma biçimi diğer bir ifadeyle işleyişi ekseninde çatışmanın meydana gelme olasıı̆ı̆ı örtük (gizli) olarak bulunmaktadır (Jones, 2017: 410). Bununla birlikte kuramsal olarak örgütsel çatışma modeli kapsamında çatışmanın altında yatan nedenler üç temel örtük çatışma aşaması üzerine yoğunlaştırılmıştır. Bunlar; (1) kıt kaynaklar için rekabet, (2) özerklik dürtüleri ve (3) alt birim hedeflerinin farklılaşması olarak ifade edilmektedir. Buna göre rekabet, katılımcıların toplu kaynak talepleri örgütün kullanabileceği kaynakları aştığında çatışmanın temelini oluşturabilir. Özerklik dürtüleri, bir tarafın ya da diğer tarafın kendi bölgesi olarak gördüğü bazı faaliyetler üzerinde denetim kurmaya çalıştığı ya da kendisini bu denetimden izole etmeye çalıştığı zaman çatışmanın temelini oluşturabilir. Son olarak hedef farklılaşması ise bazı ortak faaliyetlerde işbirliği yapması gereken iki tarafın uyumlu eylem konusunda bir fikir birliğine varamadığı durumlarda çatışmanın kaynağı olarak örtük çatışma aşaması ortaya çıkabilir (Pondy, 1967: 300). Bütün bunların sonucunda, örgütsel çatışma modeli aşamalarından örtük çatışma aşamasında; doğrudan açık bir çatışmanın olmadığı ancak birçok farkı nedenden dolayı örgütsel düzeyde çatışma potansiyelinin olduğunu söylemek mümkündür (Jones, 2017: 411).

\subsection{Algılanan Çatışma}

Pondy'nin örgütsel çatışma yönetimi aşamalarından ikincisi algılanan çatışma aşamasıdır. Asıında örgütsel düzeyde algılanan çatışmanın meydana gelmesi onun kişiselleştirildiği anlamını taşımamaktadır. Diğer bir ifadeyle taraflardan biri aralarında ciddi bir anlaşmazlık olduğunun farkında olabilir. Ancak bu durum söz konusu tarafı, rahatsız veya tedirgin etmeyebilir ve yine söz konusu tarafın karşı tarafa olan duygusal yakınlığı konusunda olumsuz bir etkisi olmayabilir. Bu durum algılanan çatışma olarak değerlendirilebilir. Bu bağlamda bir veya daha fazla tarafın çatışmanın ortaya çıkması konusunda örgütsel düzeyde koşulsal durumların farkına varması algılanan çatışma olarak ifade edilmektedir (Robbins ve Judge, 2013: 459).

Algılanan çatışma aşamasında, örgütsel düzeyde alt birimler çatışmanın farkına varır ve çatışmayı analiz etmek üzere harekete geçerler. Bununla birlikte algılanan çatışma, söz konusu grupların çatışmanın farkına vardıktan sonra çatışmanın nedenlerine yönelik tartışmaları ile birlikte hız kazanmaya başlar (Jones, 2017: 411). Örgütsel düzeyde çatışma, bazı durumlarda gizli çatışma koşulları olmadığında algılanabilir ve bazı durumlarda da katılımcılardan hiçbiri çatışmayı algılamadan bir ilişkide gizli çatışma koşulları söz konusu olabilir. Bu bağlamda gizli bir çatışma olmadığında çatışmanın algılanması durumunda, çatışma anlamsal modeli ile ele alınabilir. Bu durum, çatışmanın taraflarının birbirlerinin gerçek konumunu yanlış anlamalarından kaynaklandığını gösterebilir. Taraflar arasındaki iletişimin iyileştirilmesiyle bu tür çatışmaların çözülebileceği ileri sürülmektedir. Bu model aşaması, kişilerarası ilişkileri geliştirmeyi amaçlayan çok çeşitli yönetim tekniklerinin temelini oluşturmaktadır (Pondy, 1967: 301).

\subsection{Hissedilen Çatışma}

Örgütsel çatışma modelinin üçüncü aşaması hissedilen aşamadır. Algılanan çatışma ile hissedilen çatışma arasında önemli bir ayırım vardır. Buna göre A, B ile aralarında bazı politikalar konusunda ciddi bir anlaşmazlık içinde olduğunun farkında olabilir. Ancak bu durum A'yı gergin veya endişeli yapmayabilir ve A'nın B'ye olan sevgisini hiçbir şekilde etkilemeyebilir. Söz konusu bu durum algılanan çatışma aşaması olarak ifade edilmektedir (Pondy, 1967: 302). Buna karşııık bireyler A ve B duygusal olarak karıştıkları olay sonucunda taraflar arasında tedirginlik, düşmanlık ve düş kırıklığı olduğunda hissedilen çatışma seviyesine ulaşıldığı ortaya çıkar (Robbins ve Judge, 2013: 459). Hissedilen çatışma aşamasında, çatışma içinde yer alan alt birimler birbirlerine karşı duygusal tepkiler geliştirirler. Bununla birlikte taraflar, kendi düşüncelerini savunup birbirlerine karşı kapılarını kapatıp bize karşı onlar biçiminde kutuplaşma yoluna giderler. Çatışma arttıkça örgütsel etkililik geriler ve başlangıçta küçük olan sorunu aşmak için çaba sarf edilmezse aşılması zor büyük bir boyuta ulaşır (Jones, 2017: 413).

\subsection{Açık Çatışma}

Örgütsel çatışma modeli aşamalarından birisi olan açık çatışma, çatışma aşamaları içinde en bariz olanıdır. Bu aşama, açık saldırganlıkların olduğu ve daha az şiddet içeren biçimde niyetlerin ifade edilme eğiliminde bulunulduğu bir çatışma türüdür. Aynı zamanda bir rakibin planlarını sabote etmeye veya bloke etmeye yönelik gizli girişimler yer almaktadır (Pondy, 1967:303). Bu aşamada çatışma artık görünür bir hale gelmiştir. Çatışan gruplar, kendi niyetlerini uygulamak ve göstermek için çeşitli ifadeler, eylemler ve tepkilerde bulunurlar (Robbins ve Judge, 2013: 461). Açık çatışma aşamasında, bir alt birim diğer bir alt birimin hedeflerini engellemeye yönelik misilleme yapabilir. Dolayısıyla bu aşama, çatışmanın farkı şekillerde görüldüğü ve aktif olarak saldırganlıkların yaygın olduğu bir süreç biçiminde karşımıza çıkmaktadır. Açık çatışma aşamasının meydana gelmesinden sonra koordinasyon ve işbirliğinde aksaklıkların yaşanmaya başlamasıyla birlikte örgütsel etkililik zarar görmeye başlamaktadır (Jones, 2017: 413-415). 


\section{5. Çatışma Sonrası}

Örgütsel düzeyde her çatışma bölümü, örgüt üyeleri arasındaki ilişkileri oluşturan aşamalar dizisinden yalnızca birisidir. Buna göre çatışma gerçekten tüm üyeleri tatmin edecek şekilde çözüme kavuşturulursa işbirliğine dayalı bir ilişkinin temeli atılabilir. Diğer yandan üyeler, daha düzenli bir ilişki dürtüsünde daha önce algılanmayan ve ilgilenilmeyen gizli çatışmalara odaklanabilir. Bununla birlikte eğer çatışma sadece bastırıırsa ancak çözülmezse, gizli çatışma koşulları daha da ağırlaşabilir ve düzeltilene kadar veya ilişki çözülene kadar daha ciddi bir biçimde zararlı sonuçları olabilir. İşte bu noktada örgütsel çatışma modeli aşamasına çatışma sonrası denilmektedir (Pondy, 1967: 305). Sonuç itibariyle çatışmanın her aşaması iki tarafı da etkileyecek ve geleceğe yönelik sonuçlar üretecek bir özelliğe sahiptir. Bu bağlamda çatışma açık çatışma aşamasına gelmeden çözülebilirse ilerleyen dönemlerde örgütsel düzeyde iyi bir iş ilişkisi geliştirmek mümkün olabilir. Buna karşılık ise çatışma ilerleyen aşamalara gelmeden çözülemezse geleceğe yönelik iş ilişkileri aksar ve zarara uğrayabilir (Jones, 2017: 415).

\section{ARAŞTIRMA YÖNTEMI}

Bu araştırmada örgütsel düzeyde işletmelerde yaşanan çatışma düzeyini ve örgüt içinde Pondy'nin örgütsel çatışma modeline göre hangi çatışma aşamalarının meydana geldiğinin belirlenmesi amaçlanmaktadır. Bu amacın gerçekleştirilmesiyle birlikte yöneticiler, örgütsel çatışma modeli kapsamında örgüt içinde meydana gelen çatışmaların ortaya çıkış nedenlerine bakmaksızın çatışmayı analiz edip çözüme yönelik stratejiler geliştirebilirler. Buna göre çalışmanın amacı doğrultusunda nitel araştırma yöntemi kullanıımasına karar verilmiş ve araştırma yöntemi olarak fenomenoloji (olgu bilim) araştırma deseni seçilmiştir. Fenomenoloji (olgu bilim) araştırma deseni, özünde bize yabancı ve uzak olmayan ancak tam olarak bütünsel anlamını kavrayamadığımız olguları araştırmayı amaçlamaktadır. Aynı zamanda fenomenoloji deseni, daha önceden farkında olduğumuz bir nevi hakkında fikir sahibi olduğumuz ancak üzerinde derinlemesine ve detaylı olarak bir anlayışa hâkim olamadığımız olgular üzerine odaklanmakta ve araştırma imkânı oluşturmaktadır (Yıldırım ve Şimşek, 2016: 69). Diğer bir ifadeyle yorumlayıcı düzeyde fenomenolojik analiz, araştırma kapsamında kişi ya da grup halindeki insanların bir fenomene ilişkin yaşamış oldukları deneyimin anlamını, yapısını ve sonunda özünü anlayıp daha açık bir hale getirmeyi amaçlamaktadır (Aydın Göktepe, 2020: 35). Fenomenolojik araştırma deseni; zaman ve diğer kaynakların sınırlamaları dâhilinde bir araştırma odağı dengesini korumak için minimum yapı ve maksimum derinliğe açık bir ilke vurgusu ile tek ya da çoklu vakalara dayanabilir. Bu tür araştırmalarda diğer nitel araştırmalarda olduğu gibi görüşmeler, gözlemler, eylem araştırmaları, tartışmalar, odak grup toplantıları ve metnin analizi gibi birçok yöntem kullanılabilir. Araştırma deseninin odak noktası, araştırma katılımcısının görüş ve bakış açılarına gömülü olgunun daha derinlemesine anlaşılmasıdır. Analiz karmaşık olduğundan dolayı veriler kategorilere ayrılarak tartışmaların veya gözlemlerin farkıı bölümleri arasında çeşitli bağlantılar kurulabilir (Qutoshi, 2018: 219-220). Temelleri 18. yüzyıla dayanan nitel bir araştırma yöntemi olan fenomenoloji, "gerçek nedir?" sorusuna cevap arayan, bireysel gerçekçiliğin katılımcı ve araştırmacı tarafından birlikte oluşturulduğu çeşitli özelliklere sahip olan bir araştırma yöntemidir. Buna göre bireysel evrenin araştırılması, fenomenoloji yönteminin temel konusunu oluşturmaktadır. Bununla birlikte fenomenolojik yaklaşımın odak noktası bireysel tecrübelerdir. Özellikle araştırmacı katılımcının kişisel (öznel) tecrübeleri üzerine yoğunlaşır. Böylece araştırmalarda bireylerin algılamaları ve olaylara yüklemiş oldukları çeşitli anlamlar incelenip ele alınır (Baş ve Akturan, 2017: 85-87). Bu bağlamda araştırma kapsamı; özel sektörde faaliyet gösteren bir işletmede çalışmakta olan işgörenlerin örgütsel düzeyde iş ortamında yaşamış oldukları tecrübelere dayanarak ifade ettikleri görüşlerini ortaya koymak biçiminde tasarlanmıştır. Bu çalışmada uygulanan fenomenolojik araştırma sürecinin aşamaları dört farkıı biçimde geliştirilmiştir (Baş ve Akturan, 2017: 91-96; Yıldırım ve Şimşek, 2016: 69-72; Aydın Göktepe, 2020: 35).

i. Araştırma Konusu-Olguların Tanımlanması: Fenomenolojik araştırmada olgunun kendisi araştırılmakta olup bireylere herhangi bir müdahalede bulunulmamaktadır. Olguların tanımlanması aşamasında tanımlamalar, katılımcılardan elde edilen yazılı dokümanlardan çıkarım yapılmaktadır (Baş ve Akturan, 2017: 91-94). Bu çalışmada araştırmaya katılan işgörenlere araştırmanın konusu kapsamında iş ortamında yaşadıkları, tecrübe ettikleri ya da gözlemledikleri örgütsel çatışma aşamalarına ilişkin sorular sorulacağı, şirket ve çalışan isimlerinin gizli tutulup açıklanmayacağı konusunda bilgi verilmiştir.

ii. Örneklem-Veri Toplama Aracının Belirlenmesi: Fenomenolojik araştırmalarda araştırma kapsamında kimin araştırılacağının belirlenmesi büyük önem taşımaktadır. Özellikle fenomenolojik araştırmalarda kişisel deneyimler temel dayanak noktası olduğundan söz konusu deneyimleri yaşamış veya yaşamakta olan kişiler seçilmeli ve araştırmanın örneklemini oluşturmalıdır (Baş ve Akturan, 2017: 92). Buna göre örgütsel çatışma modeli aşamalarının farklılıklarını ortaya çıkaracak biçimde bir soru formu hazırlanmıştır. Veri toplama aracı olarak belirlenen söz konusu hazırlanan soru formunda, katılımcıların demografik özellikleri ile deneyimlerini yansıtacak düzeyde beş tane açık uçlu soru geliştirilmiştir. Sorular kuramsal düzeyde alanla ilgili literatür taramasına dayalı olarak hazırlanmış ve alanlarında uzman konuyla ilgili akademisyenlerin ve ölçme uzmanının görüşleri alınmıştır.

iii. Veri Toplama: Fenomenolojik araştırmada katılımcı ve araştırmacı arasındaki ilişki yansıma niteliklidir. Dolayısıyla araştırmalarda olguya yönelik çeşitli anlamlar çıkarabilmek için bireylerin deneyimlerinden yararlanabilecek düzeyde yazılı doküman toplanabilir (Baş ve Akturan, 2017: 92-93). Buna göre bu araştırmada özel sektörde faaliyet gösteren bir şirkette çalışmakta olan 22 kişiye soru formu gönderilerek cevaplandırmaları talep edilmiştir.

iv. Veri Analizi ve Yorumlama: Fenomenolojik araştırma, veri analizi ile elde edilen anlamlar ve yorumlamalar sonucunda bireyin tecrübelerini, bilincini, hayata ve olaylara bakış açısını ortaya koyan bir yöntemdir. Dolayısıyla buradan katılımcılara ilişkin tecrübenin ne olduğuna yönelik katıksız bir kuramsal vizyon elde etmek amaçlanmaktadır (Baş ve Akturan, 2017:9394). Bu araştırmada soru formunun gönderildiği 22 işgörenden 17 kişinin soru formunu eksiksiz olarak doldurup gönderdiği 
tespit edilmiştir. Bunun sonucunda soru formunu tam olarak dolduran 17 katılımcının araştırmaya veri sağlayabilecek düzeyde olduğu belirlenmiştir. Verilerin analiz edilmesinde fenomenoloji (olgu bilim) araştırma deseni kullanılmıştır. Elde edilen görüşler çalışmanın amacı doğrultusunda çatışma türlerinden birisine uygunluğu bakımından olumlu veya olumsuz biçiminde kategorize edilmiştir.

\subsection{Araştırmanın Örneklemi}

Araştırma örneklemini Gaziantep ilinde özel sektörde faaliyet gösteren bir işletmenin işgörenleri oluşturmaktadır. Örneklemde 17 işgören bulunmaktadır. Araştırma, Kasım-Aralık 2019 tarihleri arasında işletmede çalışan işgörenlerin katılması ile gerçekleştirilmiştir. Ticari bilgilerin mahremiyeti, işletmenin ve işgörenlerin talepleri doğrultusunda firma ve işgören bilgileri araştırma kapsamında gizli tutulmuştur. Araştırmaya katılan katılımcılara verecekleri bilgilerin gizli kalacağı söylenmiş ve onayları alınmıştır. Buna göre araştırmanın amacı doğrultusunda araştırma soru formunda; örgütsel çatışma olgusuna yönelik olarak oluşan algıyı tespit edebilmek için katılımcıların yaş, cinsiyet, medeni durum ve iş tecrübelerini içeren demografik sorulara yer verilmiştir. Bununla birlikte yine araştırma soru formunda hazırlanan açık uçlu sorular şu şekilde yer almaktadır.

Soru 1: Çalıștığınız şirkette; farklı nedenlere bağlı olarak iş arkadaşlarınızla aranızda bir çatışma potansiyeli olduğunu düşünüyor musunuz?

Soru 2: Çalıştığınız şirkette; birey veya gruplar arasında çeşitli nedenlere dayanarak yapılan işlerde birbirlerini engelleme gibi durumlarla karşılaşınız mı?

Soru 3: Çalıştığınız şirkette; birim içinde veya dışında iş arkadaşlarınızla aranızda hissettiğiniz bir kutuplaşma veya çatışma var $\mathrm{mI}$ ?

Soru 4: Çalıştığınız şirkette; birim içinde veya dışında iş arkadaşlarınızla aranızda misilleme, kavga ya da saldırganlıkların olduğu herhangi bir durum yaşadınız mı?

Soru 5: Çalıștığınız şirkette; iş arkadaşlarınızla aranızda yaşadığınız herhangi bir çatışmadan sonra iş birliği içinde çözüme kavuşturulan bir durum yaşadınız mı?

\subsection{Araştırmanın Geçerliliği ve Güvenirliliği}

Nitel araştırmalarda geçerlilik, araştırmacının araştırdığı olguyu olduğu biçimiyle ve tarafsız bir şekilde gözlemesi anlamına gelmektedir (Yıldırım ve Şimşek, 2016:269). Dolayısıyla nitel araştırmada geçerlilik, araştırmacının ele aldığı ve ilgilendiği konuyu olabildiğince tarafsız ve bütüncül bir anlayışla gözlemlemesidir (Creswell, 2013: 250). Araştırma kapsamında soru formları kodlanmıştır. Bu kapsamda araştırmanın geçerliliğini artırmak için konuyla ilgili uzman görüşlerine başvurulmuş, sorular tek tek incelenmiş ve yapılan görüşmelerin sonucunda araştırmanın geçerliliği sağlanmaya çalışımıştır. Güvenirlik ise nitel araştırmalarda birçok şekilde ele alınmaktadır. Bu bağlamda Silverman (2005), güvenirliliğe ilişkin olarak görüş birliğinin olması gerektiğini ifade etmektedir (Creswell, 2013: 253). Buna göre yapılan nitel araştırmalarda güvenirlik, görüş birliği/(görüş birliği +görüş ayrılı̆̆ı) formülü ile hesaplanmaktadır. Ayrıca araştırma kapsamında hazırlanan soru formuna verilen cevapların içerik olarak uygunluğu kapsamında belirtilen görüşlerde $\% 80$ oranında birliğin sağlanması güvenilirlik için yeterli bir düzey olarak kabul edilmektedir (Aydın Göktepe, 2020: 36). Bu araştırmada, araştırmanın güvenirliğine yönelik olarak araştırmacı ve nitel araştırma konusunda deneyimli bir uzman soru formu üzerinde elde edilen soru ve cevaplara ilişkin ayrı ayrı görüşlerini bildirmiş ve bunun sonucunda ortaya konan görüşlerde $\% 100$ görüş birliği sağlanmıştır. Buna göre araştırma kapsamında kullanılan soru formunun güvenilir olduğu ve mükemmel bir uyumun ortaya çıktığını söylemek mümkündür.

\section{BULGULAR}

Araştırma kapsamında çalışmaya dâhil edilen katılımcıların demografik özelliklerini tespit etmek amacıyla sorulan demografik nitelikli sorular çerçevesinde çeşitli veriler elde edilmiştir. Buna göre araştırmaya dâhil edilen katılımcılara ilişkin demografik özellikler tablo 1'de sunulmuştur.

Tablo 1: Demografik Sorulara iliş̧kin İstatistikler

\begin{tabular}{|l|l|c|c|}
\hline & & Frekans & Yüzde (\%) \\
\hline \multirow{3}{*}{ Cinsiyet } & Erkek & 13 & 76.47 \\
\cline { 2 - 4 } & Kadın & 4 & 23.53 \\
\hline \multirow{3}{*}{ Yaş } & 25 yaş altı & 1 & 5.88 \\
\cline { 2 - 4 } & $25-30$ arası & 6 & 35.30 \\
\cline { 2 - 4 } & 31 üstü & 10 & 58.82 \\
\hline \multirow{3}{*}{ Medeni durum } & Evli & 14 & 82.35 \\
\cline { 2 - 4 } & Bekâr & 3 & 17.65 \\
\hline
\end{tabular}




\begin{tabular}{|l|l|c|c|}
\hline & $1-3$ yıl & 4 & 23.53 \\
\hline & 3 yıl üstü & 12 & 70.59 \\
\cline { 2 - 4 } & Değişken Bazında Toplam & 17 & 100 \\
\hline
\end{tabular}

Tablo 1'de katılımcıların demografik özelliklerine ilişkin gösterilen bulgulara göre araştırmaya katılan işgörenlerin \% 76.47 'si erkek, \%23.53'ü ise kadındır. Medeni durumlarına göre incelendiğinde katılımcıların \%82.35'i evli, \%17.65'i ise bekârdır. Bununla birlikte katılımcıların yaşlarını incelediğimizde; 31 yaş ve üstünün $\% 58.82$ 'lik oranla büyük çoğunluğu oluşturduğu, işgörenlerin \%35.30'nun 25-30 yaş aralığında olduğu ve \%5.88'in ise 25 yaş altında işgörenlerden oluştukları tespit edilmiştir. Çalışma süreleri bakımından 3 yıl ve üzerinde çalışanların \%70.59'luk oranla büyük çoğunluğu oluşturduğu tespit edilmiştir. Ayrıca 1-3 yıl arasında çalışanların \%23.53 ve 1 yıldan az süre çalışanların ise \%5.88 oranında oldukları belirlenmiştir. Bununla birlikte araştırma soru formunda hazırlanan açık uçlu sorulara verilen cevaplar oransal olarak kategorize edilmiştir. Buna göre, araştırmaya dâhil edilen katılımcıların, oluşturulan soru formunda yer alan açık uçlu sorulara verdikleri cevaplara yönelik dağılımların sırasıyla yüzdesel olarak değerleri sunulmuştur.

Soru 1: Çalıştığınız şirkette; farklı nedenlere bağlı olarak iş arkadaşlarınızla aranızda bir çatışma potansiyeli olduğunu düşünüyor musunuz?

Soru 1'e verilen cevaplar kapsamında; araştırmaya katılan işgörenlerin \%58.82'si çalıştığı şirkette farklı nedenlere bağıı olarak iş arkadaşlarıyla aralarında bir çatışma potansiyeli olduğunu düşünüp evet derken, \%41.18'i ise böyle bir çatışma potansiyeli olmadığını düşünüp hayır cevabını vermiştir. Buna göre, işgörenler çalıştıkları şirkette diğer işgörenlerle aralarında bir çatışma yaşama olasılığının daha yüksek olduğu eğilimindedirler. Söz konusu bu durum, işgörenlerin potansiyel çatışma yaşamalarının diğer bir ifadeyle şirket içinde çatışma çıkma olasılığının mevcut olduğunu göstermektedir. Bu bağlamda çatışma olasılığının yüksek olduğunu düşünen işgörenlerin; gözlemlerine, deneyimlerine ve örgüt iklimine bağlı olarak görüş bildirdiklerini ifade edebiliriz. Buna karşılık çatışma olasılığının olmadığını düşünen işgörenler ise; isminin açığa çıkabileceğini düşünerek gerçek görüşünü ifade etmemesi, çatışma olasılı̆̆ının olmadığını düşünmesi, içinde yaşadığı olası çatışma ihtimalini algılayamaması, yanlış yorumlaması ya da uzun dönemde yaşanabilecek bir çatışmayı öngörememesi gibi çeşitli nedenlere bağlı olarak görüş bildirdiklerini söyleyebiliriz. Elde edilen cevapların oransal dağılımlarına bakarak araştırma kapsamında, doğrudan çatışmanın olmadığı ancak işgörenlere, örgütün yapısına ve işleyişine bağlı olarak çatışma ihtimalinin yüksek olduğu diğer bir ifadeyle gizli bir çatışma durumunun varlığı belirlenmiştir. Bu bağlamda; soru 1'den elde edilen bulgular doğrultusunda, Pondy'nin örgütsel çatışma modeline göre araştırma kapsamında ele alınan şirket içinde örtük çatışma durumunun yaşandığını söylemek mümkündür.

Soru 2: Çalıştığınız şirkette; birey veya gruplar arasında çeşitli nedenlere dayanarak yapılan işlerde birbirlerini engelleme gibi durumlarla karşılaştınız mı?

Soru 2'ye verilen cevaplara göre araştırmaya katılan işgörenlerin; çalıştıkları şirkette birey veya gruplar arasında çeşitli nedenlere dayanarak yapılan işlerde birbirlerini engelleme gibi durumlarla karşılaştıklarını belirten ve evet diyenlerin oranı \%70.59 olarak tespit edilmiştir. Buna karşılık işgörenlerden; "hayır", şirkette yapılan işlerde birey veya gruplar arasında çeşitli nedenlere dayanarak birbirlerini engelleme durumlarıyla karşılaşmadım diyenlerin \%29.41 oranında oldukları belirlenmiştir. Buna göre katılımcıların \%70.59 gibi yüksek bir çoğunluğu, şirket içinde yapmış ya da yapmayı planladığı bir faaliyetin birim içindeki gruplar ya da bireysel faktörler tarafından çeşitli nedenlerle dolaylı veya doğrudan engellendiğini düşünmektedirler. Diğer yandan \%29.41 oranındaki işgörenler ise; şirket içinde bulundukları ya da tasarladıkları faaliyetler konusunda herhangi bir engelle karşılaşmadıkları yönünde görüş bildirmişlerdir. Bu bağlamda evet diyenlerin; yaşadıkları işin özelliğine bağıı olarak çeşitli aksaklıklar yaşaması veya işle ilgili yaşanan problemlerden diğer grup veya bireyi sorumlu olarak tutmaları nedenlerine bağlı olarak şirket içinde algıladıkları bir çatışmanın varlığı yönünde görüş bildirdiklerini ifade edebiliriz. Buna karşııı hayır diyenlerin ise herhangi bir işle ilgili yaşanan aksaklık durumunun dolaylı ya da doğrudan herhangi bir grup veya birey tarafından kaynaklandığına yönelik bir çatışma durumunu algılamadıkları, ortaya çıkan problemlerin işin yapısından kaynaklandığını düşünmeleri ya da var olan sorunu kabul etmek istememeleri gibi faktörler yönünde görüş bildirdiklerini söyleyebiliriz. Araştırma kapsamında elde edilen bulgular doğrultusunda katılımcıların görüşleri çerçevesinde; Pondy'nin örgütsel çatışma modeline göre şirket içinde algılanan çatışma durumunun yaşandığını söylemek mümkündür.

Soru 3: Çalıştığınız şirkette; birim içinde veya dışında iş arkadaşlarınızla aranızda hissettiğiniz bir kutuplaşma veya çatışma var $m ı$ ?

Soru 3'e verilen cevaplar doğrultusunda, katılımcıların \%64.71'i çalıştıkları şirkette birim içinde veya dışında iş arkadaşlarıyla aralarında hissettikleri bir kutuplaşma veya çatışma olduğunu belirtmiş ve evet demişlerdir. Buna karşılık çalıştıkları şirkette birim içinde veya dışında iş arkadaşlarıyla aralarında hissettikleri bir kutuplaşma veya çatışma olmadığını belirtip hayır diyenlerin oranı ise \%35.29 olarak belirlenmiştir. Buna göre araştırma kapsamında ele alınan şirket genelinde çalışan işgörenlerin \%64.71 oranında büyük çoğunluğunun bir çatışma hissettiğini ifade edebiliriz. Araştırmaya dâhil edilen işgörenlerin çalıştıkları kurum içinde hissedilen düzeyde bir çatışma durumunu yaşadıklarını ifade etmelerinde çeşitli nedenler ileriye sürmek mümkündür. Bu nedenler; şirket içinde çalışanların genel olarak birbirlerini suçlamaları, gruplar halinde kutuplaşmış yapılar oluşturması, işgörenlerin kendi düşüncelerini aşırı derecede savunması ve diğer çalışanlara kabul ettirmek istemesi, örgüt içinde yaşanan herhangi bir olay karşısında işgörenlerin birbirlerine karşı kolay duygusal tepkiler vermesi şeklinde sıralanabilir. Bu bakımdan söz konusu nedenlere bağlı olarak işgörenlerin hissedilen çatışma yönünde görüş bildirdiklerini ifade edebiliriz. Diğer yandan şirket içinde hissedilen yönde bir çatışma yaşamadıkları yönünde görüş 
bildirenlerin ise; birlikte çalıştıkları diğer işgörenlere göre küçük ya da büyük düzeyde herhangi bir soruna karşı duygusal tepki vermemesi, gruplar arasında taraf olmaması ya da objektif değerlendirmelerde bulunmaması gibi nedenler ileri sürülebilir. Bu bağlamda araştırma kapsamında elde edilen bulgular doğrultusunda; ele alınan şirket içinde Pondy'nin örgütsel çatışma modeli aşamalarından hissedilen çatışma durumunun yüksek düzeyde görüldüğünü söyleyebiliriz.

Soru 4: Çalıștığınız şirkette; birim içinde veya dışında iş arkadaşlarınızla aranızda misilleme, kavga ya da saldırganlıkların olduğu herhangi bir durum yaşadınız mı?

Soru 4'e verilen cevaplar kapsamında; araştırmaya katılan işgörenlerin \%23.53'ü çalıştığı şirkette birim içinde veya dışında iş arkadaşlarıyla arasında misilleme, kavga ya da saldırganlıkların olduğu bir durum yaşadığını belirtmiş ve evet demiştir. Diğer yandan işgörenlerin \%76.47'si ise böyle bir kavga, misilleme ya da saldırı durumu ile karşılaşmadığını ifade edip hayır cevabını vermiştir. Elde edilen bu veriler doğrultusunda şirket içinde çalışan bireyler arasında aktif veya pasif bir saldırganlık düzeyinin diğer bir ifadeyle açık düzeyde bir çatışma durumunun olmadığı sonucunu çıkarmamız mümkündür. Bununla birlikte düşük düzeyde de olsa şirket içinde işgörenlerin birbirlerini engellemeye ve bireysel çıkarlarını korumaya yönelik farklı şekillerde açık bir çatışma durumunun yaşandığını söyleyebiliriz. Bütün bunların sonucunda araştırma kapsamında elde edilen bulgular çerçevesinde; Pondy'nin örgütsel çatışma modeline göre şirket içinde açık çatışma durumunun düşük düzeyde yaşandığını söylemek mümkündür.

Soru 5: Çalıştığınız şirkette; iş arkadaşlarınızla aranızda yaşadığınız herhangi bir çatışmadan sonra iş birliği içinde çözüme kavuşturulan bir durum yaşadınız mı?

Soru 5'e verilen cevaplara göre araştırmaya katılan işgörenlerin; çalıştıkları şirkette iş arkadaşlarıyla aralarında yaşadıkları herhangi bir çatışmadan sonra iş birliği içinde çözüme kavuşturulan bir durumla karşılaştıklarını belirtenlerin ve evet diyenlerin oranı \%29.41 olarak tespit edilmiştir. Buna karşılık işgörenlerden; "hayır", şirkette iş arkadaşlarımızla aramızda yaşadığımız herhangi bir çatışmadan sonra iş birliği içinde çözüme kavuşturulan bir durumla karşılaşmadım diyenlerin oranının \%35.29 oldukları belirlenmiştir. Buna göre katılımcıların \%70.59 oranında büyük çoğunluğunun şirket içinde çatışma sonrasında işbirliği içinde çözüme yönelik kararların alındığı ve uygulamaların yapıldığı yönünde görüş bildirdiklerini ifade etmek mümkündür. Özellikle ele alınan şirket çerçevesinde örgütsel düzeyde işgörenlerin işbirliği içinde çatışma sonrasında çözüm odaklı yaklaşımlarla karşılaştıklarını söyleyebiliriz. Bu bağlamda araştırma kapsamında elde edilen bulgular doğrultusunda; ele alınan şirket içinde Pondy'nin örgütsel çatışma modeli aşamalarından çatışma sonrası durumunun yüksek düzeyde uygulandığını söylemek mümkündür.

\section{SONUÇ}

Örgütsel literatür incelendiğinde, örgütlerin bir örgüt olarak meydana gelen çatışmalara karşı açık ve hazırlıklı olmaları, çatışmaları tespit etmeleri, kontrol etmeleri ve sisteme uygun bir şekilde yönetmelerinin önemli olduğu görülmektedir. Aynı zamanda örgütsel düzeyde normatif amaçlara bağlı olarak taraflar arasında yaşanan çatışma aşamalarının doğru bir biçimde konumlandırılmasının gerekli olduğu sonucuna ulaşabiliriz. Bu çerçevede örgütsel düzeyde belirlenen doğru konular üzerinde çatışma yönetimine göre doğru temel kurallar altında hareket etmek gerekmektedir. Söz konusu durum, açık olarak yöneticilerin işlevlerine yönelik uygulanacak bir sistemin aşamalarını kabul etmek demektir. Örgütsel düzeyde meydana gelebilecek çatışmaların çok farklı şekillerde ve örgütsel davranış odaklı yaklaşımların temelinde dinamik bir süreç olarak ele alınması gerektiğini söylemek mümkündür. Bu bakımdan örgütsel çatışma; koşulsal durumlara, bireysel ve grupsal farklılıklara, duygusal durumlara ve tepkilere, yapısal işleyişe bağlı olarak bir bütün olarak tüm bileşenleri yapısında bulunduran çok yönlü bir süreçtir.

Örgütsel çatışma ele alıııken çatışmanın sadece olumlu ya da olumsuz tarafı değil aynı zamanda bireysel ve örgütsel düzeyde yapısal işleyiş ve işlevsel aksaklıkların ortaya çıkarılması bakımından düşünülmeli ve harekete geçilmelidir. Genel olarak meydana gelen örgütsel çatışma, mevcut çatışmayı azaltmak ya da ortadan kaldırmak için baskı oluşturmasına rağmen süregelen çatışma hali devam eder ve koşulsal durumlar çerçevesinde yönetici tarafından bilinçli olarak yönetilmeye çalışılır. Bununla birlikte çatışmanın tespit edilmesi ve yönetilmesi aşamasının örgütsel etkililiğe faydası çatışmanın doğasına ve yöneticinin yönetim felsefesine bağlı olarak gelişim gösterir. Aynı zamanda örgütsel düzeyde iletişim kanallarının açık olması büyük önem taşır. Özellikle örgüt içindeki üyeler arasında meydana gelen çatışmanın temel belirleyicisinin hedeflerin farklılaşması olduğu ileri sürülebilir. Bu noktada örgütsel çatışma modeli bağlamında her bir çatışma türü tespit edilip üyeler arasındaki işbirliği, rekabet ve değişim yönetimi sağlanmalıdır.

Bu çalışmanın amacı doğrultusunda örgütsel çatışma modeline göre örgütsel düzeyde çatışmayı etkin bir şekilde tespit etmek, analiz etmek, yönetmek ve kontrol etmek için değerlendirmelerde bulunmaya çalışımıştır. Araştırma kapsamında örgüt içinde yaşanan çatışmaların düzeyi ve örgütsel düzeyde Pondy'nin örgütsel çatışma modeline göre hangi çatışma aşamalarının meydana geldiği tespit edilmeye çalışımıştır. Bu bağlamda yöneticiler, örgütsel çatışma modeli kapsamında örgüt içinde meydana gelen çatışmaların ortaya çıkış nedenlerine bakmaksızın çatışmayı analiz ederek nedenler üzerinde yoğunlaşarak çözüme yönelik alternatif stratejiler geliştirme yollarına gidebilirler.

Araştırma kapsamında elde edilen bulgular sonucunda Pondy'nin örgütsel çatışma modeli aşamalarından örtük çatışmanın incelemeye tabi tutulan işletme içinde görülme oranı \%58,82 olarak tespit edilmiştir. Buna göre örgüt içinde çalışanların bizzat kendilerinin ya da gözlemledikleri diğer çalışanların örtük (gizli) bir çatışma içinde oldukları belirlenmiştir. Örtük çatışma aşamasında açık bir çatışma hali olmamasına rağmen bireysel veya grupsal düzeyde farklı nedenlere dayanan bir çatışma potansiyeli bulunmaktadır. Söz konusu çatışma aşmasının ortaya çıkmasının nedenlerini; örgütsel işleyişe bağlı olarak gruplar 
veya bireyler arasında iş yapma farklıııklarının olması, değer yaratma konusunda farklı yöntemsel düşüncelere sahip olma ve kısa ve uzun dönemde önceliklerin belirlenmesinde ayrılıkların yaşanması şeklinde sıralamak mümkündür.

Bu çalışmada, incelenen işletmede yapılan araştırma kapsamında elde edilen bulgular sonucunda Pondy'nin örgütsel çatışma modeli aşamalarından algılanan çatışma aşamasının görülme oranının \%70,59 olduğu belirlenmiştir. Buna göre araştırma kapsamında incelenen işletmede görülen en yüksek örgütsel çatışma modeli aşamasının algılanan çatışma aşaması olduğu tespit edilmiştir. Oransal olarak algılanan çatışma aşamasının yüksek olması bize işletme içinde bireyler veya gruplar arasında taraflardan en az birinin rahatsız, tedirgin ve duygusal olarak olumsuz bir etkiye sahip olduğunu göstermektedir. Bununla birlikte işletme içinde en çok görülen çatışma türünün algılanan çatışma olmasının nedenleri; işin mahiyeti, bireylerin iş yapma pratikleri ve kültürel yapıları, koşulsal durumların farkına varılması ve çatışmanın nedenlerine yönelik yanlış konumlama olarak sıralamak mümkündür.

Araştırma kapsamında elde edilen bulgular sonucunda analiz edilen işletmede Pondy'nin örgütsel çatışma modeli aşamalarından hissedilen çatışma türünün görülme oranının \% 64.71 olduğu tespit edilmiştir. Buna göre işletme genelinde hissedilen çatışma türünün de algılanan çatışma türü gibi yüksek oranlarda görüldüğü belirlenmiştir. Bu oranlar, örgütsel düzeyde bireylerin veya grupların aralarında tedirginlik, düşmanlık veya hayal kırıklığına uğrama şeklinde verdikleri duygusal tepkilerin algılanan çatışma seviyesinden hissedilen çatışma seviyesine yükseldiğini göstermektedir. Aynı zamanda oransal olarak örgüt içinde meydana gelen çatışma seviyelerinin algılanandan hissedilen çatışmaya dönüşme oranı birbirine yakındır. Elde ettiğimiz bu veri bize çalışanların herhangi bir çatışma algıladıkları zaman bunun hissedilen çatışmaya dönüşümünün muhtemel olduğunu göstermektedir.

Bu çalışmada analiz edilen işletme kapsamında elde edilen bulgulara göre Pondy'nin örgütsel çatışma modeli aşamalarından açık çatışma türünün \%23.53 oranında görüldüğü belirlenmiştir. Bu kapsamda açık çatışma türünün işletmede genelinde en az görülen çatışma türü olduğu tespit edilmiştir. Söz konusu bu durum bize, analize dâhil edilen örgüt genelinde üyeler veya gruplar arasında aktif saldırganlıkların olmadığını, görünür düzeyde bir çatışmanın yaşanmadığını ve bireylerin niyetlerini göstermek için eylem ya da herhangi bir tepkide bulunmadıklarını göstermektedir. Buradan işletme genelinde meydana gelen çatışma türlerinin ve düzeylerinin genel olarak aktif bir düzeyde değil pasif düzeyde eylemlere dayanan yapısal bir özellik gösterdiğini sonucuna ulaşmamız mümkündür. Diğer bir ifadeyle örgüt üyelerinin niyetlerinin eylemlere dönüşme düzeylerinin ve duygusal tepkilerini gösterme eğilimlerinin düşük düzeyde olduğu göreceli olarak pasif bir nitelik taşıdığını ifade etmemiz mümkündür.

Son olarak araştırma sonucunda elde edilen bulgular doğrultusunda ele alınan işletme genelinde Pondy'nin örgütsel çatışma modeli aşamalarından çatışma sonrası aşamasının \%29.41 oranında görüldüğg̈ belirlenmiştir. Buna göre işletme genelinde görülen çatışma sonrası aşamasının yaklaşık olarak açık çatışma aşaması oranında olduğu tespit edilmiştir. Örgüt genelinde herhangi bir örgütsel çatışma aşamasının ardından çatışma sonrası aşamaya kadar mevcut çatışma çözüme ulaştırılamazsa açık çatışma aşaması düzeyine ulaşılır. Açık çatışma aşamasından sonra çatışma sonrası aşamada ise örgütsel ve bireysel düzeyde iş ilişkilerine, iş birliğine ve örgüt uyumuna zarar verecek şekilde sonuçlar meydana gelmesi beklenmektedir. Bununla birlikte eğer örgütte meydana gelen bir çatışma açık çatışma aşamasına kadar çözüme kavuşturulursa o zaman örgütsel düzeyde iş birliği sağlanır ve geleceğe yönelik iş ilişkilerinin ve örgütsel işleyişin önü açıır. Çatışma sonrası aşamasının; örgütsel ve bireysel düzeyde işbirliğinin sağlanması, iş ilişkilerinin ve akışının geliştirilmesi ya da örgütsel işleyişin ve işletmenin geleceğe yönelik planlarının uygulanmasına yönelik adımların uygulanmasına zarar verecek sonuçlar üretebilecek bir niteliğe sahip olduğunu söylemek mümkündür.

Örgütsel düzeyde örgütsel çatışma türlerinin örgüt ve üyelerinin yapılarına bağlı olarak değişmekle birlikte ortaya çıkış biçimlerinin temel nedenlerini genel olarak sıralamak mümkündür. Bu nedenler: örgüt yapısı ve işleyişi, işin niteliği, bireysel hedef farklıııları ve öncelik konumlama, farklı düzeylerde değer yargılarına, kültüre ve bakış açılarına sahip olma biçiminde sıralanabilir. Bununla birlikte performansa bağlı verilerin yorumlanmasına yönelik uygulamalar, gruplar veya bireyler arasında kıskançlık yaşanması, formal nitelikli nedenler (ihale yapılması, finansal kredi desteği sağlanması, yapılan işlerin likidite dönüşü), kaynakların dağıımında dengesizlik yaşanması, işin doğası gereği karşıııklı ve bağımlı iş yapma zorunluluğu çatışmaların yaşanmasının diğer nedenleri olarak sıralanabilir. Bu çalışma kapsamında ele alınan işletme genelinde en çok meydana gelen Pondy'nin örgütsel çatışma türlerinin algılanan ve hissedilen çatışma türleri olduğu görülmektedir. Bu durum bize işletme genelinde, algılanan ve hissedilen çatışmalar bağlamında işin niteliği, kıskançlık, performans ile hedef farklııkları ve öncelik konumlama nedenlerine bağlı olarak bireyler veya gruplar arasında tek taraflı (algılanan) ya da karşılıkı (hissedilen) düzeyde tedirginlik, düşmanlık, kutuplaşma, hayal kırıklığına uğrama biçiminde duygusal tepkilerin geliştirildiğini ve yaşandığını göstermektedir. Bu bağlamda Pondy'nin örgütsel çatışma modeli yardımıyla yöneticiler işletmede meydana gelen çatışmaları tespit etme, kontrol etme ve yönetme şansına sahip olabilirler. Aynı zamanda çatışmaların tespit edilmesiyle birlikte açık çatışma aşamasına kadar çatışmalara çözüm yolu bulunabildiği takdirde yöneticilere, örgütsel düzeyde geleceğe yönelik iş birliği, örgütsel performans ve iş geliştirme konularında yardımcı olabilecek ve farklı çözüm odaklı stratejiler geliştirmelerine imkân sağlayabilecektir. Bu bakımdan örgüt genelinde meydana gelebilecek her türlü düzeyde çatışma açık çatışma aşamasına gelmeden önce tespit edilmeli ve daha sonra çözüme kavuşturulmalıdır. Bu sayede çatışmanın işlevsel ve dinamik nitelikli özelliklerinden yararlanarak örgütsel ve bireysel düzeyde fayda sağlamak mümkün olabilecektir.

Çalışmanın sınırıııkları, örneklem sayısının azlı̆̆ı ve tek bir sektörde hizmet veren bir örgütün ele alınması olarak gösterilebilir. Buna karşılık araştırmanın yöntemi olarak çok az çalışmada görülen ve kullanılan fenomenolojik araştırma yönteminin kullanılmasının çalışmaya bir değer katabileceği düşünülmektedir. Aynı zamanda örgütlerde çatışmayı tespit etmek, kontrol 
etmek ve yönetmekle ilgili yol gösterici bir niteliğe sahip olan Pondy’nin örgütsel çatışma modeli yaklaşımının kullanılmasının işletmelere fayda sağlayabileceği söylenebilir. Günümüzde örgütlerin yönetiminde önemli görülen ve üzerinde stratejiler geliştirip önlemler alınması gereken bir kavram olarak değerlendirilen çatışmanın örgütsel çatışma modeli yaklaşımı bağlamında temel alınarak kullanılması ve analiz edilmesiyle birlikte çalışmanın literatüre özgün bir katkı sunacağı düşünülmektedir.

\section{KAYNAKÇA}

Anderson, G. (1990) Fundamentals of education research. London: The Falmere Press.

Aydın Göktepe, E. (2020). Pandemi döneminde bireylerin uzaktan (evden) çalışma modeli algısını belirlemeye yönelik fenomenolojik bir araştırma; kamu üniversitesi örneği. Journal of Current Researches on Business and Economics, 10(1): 29-42.

Baş, T. \& Akturan, U. (2017). Sosyal bilimlerde bilgisayar destekli nitel araştırma yöntemleri. Ankara: Seçkin Yayıncılık.

Blake, R. R., \& Mouton, J. S. (1964). The managerial grid. Houston, TX: Gulf Publishing Co.

Burton, J. W. (1987). Resolving deep rooted conflict. Virginia: Centre for Conflict Resolution.

Conbere, J. P. (2001). Theory building for conflict management system design. Conflict Resolution Quarterly, 19(2): $215-236$.

Creswell, J. W. (2013). Nitel Araştırma Yöntemleri. Bütün M., \& Demir, S. B. (Ed.), Ankara: Siyasal Kitabevi.

De Dreu, C. K. W. \& Beersma, B. (2005). Conflict in organizations: Beyond effectiveness and performance. European Journal of Work and Organizational Psychology, 14 (2): 105-117.

Demir Uslu, Y. (2018). Örgütsel çatışma. Aydoğan, E. (Ed.), Örgütsel davranış odaklı yönetsel yaklaşımlar içinde (s.119-130). Ankara: Gazi Kitabevi.

Deutsch, M. (1949). A theory of cooperation and competition. Human Relations, 2, 129-151.

Eisenhardt, K. M., Kahwajy, J. L., \& Bourgeois, L. J. (1998). Conflict and strategic choice: How top management teams disagree. In Hambrick, D. C., Nadler, D. A., \& Tushman, M. L. (Eds.), Navigating change: How CEOs, top teams, and boards steer transformation (p.141-169). Boston: Harvard Business School Press.

Follett, M.P. (1942). Constructive conflict. In Metcalf, H.C., \& Urwick, L. (Eds), Dynamic Administration: The Collected Papers of Mary Parker Follett (p.30-49). New York, NY: Harper.

Jones, G. R. (2017). Örgüt kuramı, örgüt tasarımı ve örgütsel değişim. Altın Gülova, A., Oral Ataç, L., \& Dirik, D. (Ed.), Ankara: Gazi Kitabevi.

Lewicki, R. J., Saunders, D.M., \& Minton, J. W. (1997). Essentials of negotiation. Chicago, IL: Irwin.

Madalina, O. (2016). Conflict Management, a new challenge. Procedia Economics and Finance, 39, 807-814.

Montes, C., Rodriguez, D., \& Serrano, G. (2012). Affective choice of conflict management styles. International Journal of Conflict Management, 23(1): 6-18.

Munduate, L., Ganaza, J., Peiro, J. M., \& Euwema, M. (1999). Patterns of styles in conflict management and effectiveness. The International Journal of Conflict Management, 10(1): 5-24.

Omisore, B. O., \& Abiodun, A. R. (2014). Organizational conflicts: Causes, effects and remedies. International Journal of Academic Research in Economics and Management Sciences, 3(6): 118-137.

Pondy, L. R. (1966). A systems theory of organizational conflict. The Academy of Management Journal, 9(3): 246-256.

Pondy, L. R. (1967). Organizational conflict: Concepts and models. Administrative Science Quarterly, 12(2): 296-320.

Pondy, L. R. (1989). Reflections on organizational conflict. Journal of Organizational Change Management, 2(2): 94-98.

Qutoshi, S. B. (2018). Phenomenology: A philosophy and method of inquiry. Journal of Education and Educational Development, 5(1): 215222.

Rahim, M. A. (2002). Toward a theory of managing organizational conflict. The International Journal of Conflict Management, 13 (3): $206-235$. Rahim, M. A. (2011). Managing Conflict in Organizations. New Brunswick, New Jersey: Transaction Publishers.

Rahim, M. A., \& Bonoma, T. V. (1979). Managing organizational conflict: A model for diagnosis and intervention. Psychological Reports, 44, 1323-1344.

Robbins, S. P., \& Judge, T. A. (2013). Örgütsel davranış. Erdem, İ., (Ed.), Ankara: Nobel Akademik Yayıncılık.

Roloff, M. E. (1987). Communication and conflict. In Berger, C. R., \& Chaffee, S. H. (Eds.), Handbook of communication science (p.484-534). Newbury Park, CA: Sage.

Rubin, J. Z., Pruitt, D. G., \& Kim, S.H. (1994). Social conflict: Escalation, stalemate, and settlement. New York, NY: McGraw-Hill.

Silverman, D. (2005). Doing qualitative research: A practical handbook. London: Sage.

Thakore, D. (2013). Conflict and conflict management. IOSR Journal of Business and Management, 8(6): 7-16. 
Tjosvold, D. (2006). Defining conflict and making choices about its management: Lighting the dark side of organizational life. International Journal of Conflict Management, 17(2): 87-95.

Trippe, B. \& Baumoel, D. (2015). Beyond the Thomas-Kilmann Model: Into extreme conflict. Negotiation Journal, 31(2): 89-103.

Wall, J. A. \& Callister, R. R. (1995). Conflict and its management. Journal of Management, 21(3): 515-558.

Yıldırım, A. \& Şimşek, H. (2016). Sosyal bilimlerde nitel araştırma yöntemleri. Ankara: Seçkin Yayıncılık. 